\title{
Anticancer cytotoxicity assessment of cationic surfactants metal complexes
}

\author{
Nabel A. Negm ${ }^{1 \#}$, Dalia E. Mohamed ${ }^{1}$, Medhat M. Said ${ }^{2}$, Ali Abdel Aal ${ }^{1}$ \\ 1. Petrochemicals Department, Egyptian Petroleum Research Institute, Cairo, EGYPT \\ 2. Organometallic and Organometalloid Department, National Research Center, Dokki, Giza, EGYPT.
}

\begin{abstract}
Series of metal complexes $(\mathrm{Cu}, \mathrm{Co}, \mathrm{Ni}, \mathrm{Y})$ was prepared by the reaction of the different transition metals and three environmentally cationic surfactants derived from vanillin. Their chemical structures were confirmed using IR, NMR, UV-Vis, dynamic light scattering $(D L S)$ spectroscopy, and zeta potential. The surface activities of the ligands and their metal complexes were measured using surface tension measurements. Their Surface and thermodynamic parameters were calculated at $25{ }^{\circ} \mathrm{C}$. Chemical structure-surface activity relationship of the metal complexes was discussed. The anticancer cytotoxic assessment of the synthesized metal complexes showed promising results in the medicinal field.
\end{abstract}

Key words: Surface activity; metal complex; cytotoxicity; anticancer.

\section{Introduction}

Medicinal inorganic chemistry [1-3] is a field of increasing prominence as metal-based compounds offer possibilities for the design of therapeutic agents not readily available to organic compounds. The wide range of coordination numbers and geometries, accessible redox states, thermodynamic and kinetic characteristics, and the intrinsic properties of the cationic metal ion and ligand itself offer the medicinal chemist a wide spectrum of reactivity that can be exploited. Although metals have long been used for medicinal purposes in a more or less empirical fashion [4], the potential of metal-based anticancer agents has only been fully realized and explored since the landmark discovery of the biological activity of cis-platin [5]. To date, this prototypical anticancer drug remains one of the most effective chemotherapeutic agents in clinical use. The clinical use of cis-platin against this and other malignancies is, however, severely limited by dose-limiting sideeffects such as neuro-, hepato and nephrotoxicity [5]. In addition to the high systemic toxicity, inherent or acquired resistance is a second problem often associated with platinum-based drugs, with further limits their clinical use. Much effort has been devoted to the development of new platinum drugs and the elucidation of cellular responses to them to alleviate these limitations [6]. These problems have also prompted chemists to develop alternative strategies based on different metals and aimed at different targets. Cationic surfactants metal complexes showed acceptable activity against the growth of several types of tumors [7-8]. The antitumor cytotoxicity was merely dependent on the transition metal types and also the chemical structures of the ligand surfactants. In this study, we prepared series of metal complexes $(\mathrm{Cu}, \mathrm{Co}, \mathrm{Ni}$, and $\mathrm{Y})$ by the reaction of the transition metals and recently published three environmentally cationic surfactants derived from vanillin. The metal complexes were characterized by: FTIR, NMR, UV-Vis, dynamic light scattering (DLS) spectroscopy, and their surface activity was determined. The anticancer activity of the different metal complex was tested against HuH-7 cell line.

\section{Experimental}

\section{Synthesis of cationic surfactants transition metal complexes}

The synthesis of the cationic surfactants used in this study was briefly described in our recent publication [9]. The metal complexes were synthesized by heating 0.1 mole of transition metal salts $\left(\mathrm{CoCl}_{2} \cdot 6 \mathrm{H}_{2} \mathrm{O}, \mathrm{CuCl}_{2}, \mathrm{NiCl}_{2}\right.$, $\left.\mathrm{Y}\left(\mathrm{NO}_{3}\right)_{3} \cdot 6 \mathrm{H}_{2} \mathrm{O}\right)$ and 0.2 mole of the different cationic surfactants under reflux condition in $150 \mathrm{~mL}$ of ethanol for $12 \mathrm{~h}$. The reaction mixture was then allowed to cool and the precipitate was filtered off. The products were recrystallized twice from ethanol and dried under vacuum.

Elemental analysis

Elemental analysis of the synthesized metal complexes was performed using Vario Elementar instrument, USA. IR spectra

Infrared spectroscopic analysis of the synthesized surfactants was performed for the $\mathrm{KBr}$ disk method using a Fourier-transform infrared spectrophotometer (FTIR).

\section{${ }^{1}$ H-NMR spectra}

${ }^{1} \mathrm{H}-\mathrm{NMR}$ spectra were recorded using Varian NMR-300 Mercury $300 \mathrm{MHz}$ spectrometer with trimethyl silane (TMS) as an internal standard and DMSO-D ${ }^{6}$ as a solvent.

\section{UV-Vis spectroscopy}


UV-Vis spectra of the different compounds were carried out at 200-800 nm using a 3-5 mm quartz cuvette using UV-Vis Perkin Elmer Lambda 25 spectrophotometer (United Kingdom). All the measurements were carried out at room temperature.

\section{Surface Tension Measurements}

Surface tension measurements performed using a K-6 Du-Noüy Tensiometer (Krüss GmbH, Germany). The tensiometer was calibrated before the surface tension measurements using bidistilled water to obtain the standard surface tension value of the bidistilled water $\left(71.8 \mathrm{mN} / \mathrm{m}\right.$ at $\left.25{ }^{\circ} \mathrm{C}\right)$. Freshly prepared aqueous surfactants solutions, with a concentration range of 0.01 to $0.000001 \mathrm{~mol} / \mathrm{L}$, were poured into a clean $30 \mathrm{~mL}$ Teflon cup with $28 \mathrm{~mm}$ mean diameter. Apparent surface tensions were measured minimum of three times at $25 \pm 0.2{ }^{\circ} \mathrm{C}$. The platinum ring was then removed, washed with diluted $\mathrm{HCl}$ followed by distilled water [10]. All experiments were repeated at least twice, the tensiometer sensitivity was $0.5 \mathrm{mN} / \mathrm{m}$ and the reproducibility of the measurements was within $\pm 2 \%$.

\section{Reagents}

\section{Biological Methodology}

Cells were grown in Dulbecco's Modified Eagle Medium (DMEM) as cell culture medium which can be used to maintain cells in tissue culture. The chemical composition of DMEM is (mg/L): $\mathrm{CaCl}_{2} \cdot 2 \mathrm{H}_{2} \mathrm{O}: 264.92$, Ferric Nitrate $\left(\mathrm{Fe}\left(\mathrm{NO}_{3}\right)_{3} .9 \mathrm{H}_{2} \mathrm{O}\right)$ : 0.1, Potassium Chloride $(\mathrm{KCl})$ : 400, $\mathrm{MgSO}_{4} \cdot 7 \mathrm{H}_{2} \mathrm{O}: 200$, Sodium Chloride $(\mathrm{NaCl}): 6400$, Sodium Bicarbonate $\left(\mathrm{NaHCO}_{3}\right): 3700$, Sodium Phosphate $\left(\mathrm{NaH}_{2} \mathrm{PO}_{4}-\mathrm{H}_{2} \mathrm{O}\right): 125$, Arginine- $\mathrm{HCl}$ : 84, Cystine: 48, Glycine: 30, Histidine $\mathrm{HCl}-\mathrm{H}_{2} \mathrm{O}: 42$, Isoleucine: 105, Leucine: 105, Lysine-HCl: 146, LMethionine: 30, L-Phenylalanine: 66, L-Serine: 42, L-Threonine: 95, L-Tryptophan: 16, L-Tyrosine: 72, LValine: 94, VITAMINS: D-Calcium pantothenate: 4, Choline Chloride: 4, Folic Acid: 4, i-Inositol: 7.2, Niacinamide: 4, Pyridoxal $\mathrm{HCl}$ : 4, Riboflavin: 0.4, Thiamine $\mathrm{HCl}$ : 4.

\section{Cell line}

HuH-7 used in this study is a well differentiated hepatocyte derived cellular carcinoma cell line.

\section{Cell culture}

Huh-7, human hepatoma cell line was grown in DMEM with high glucose level $0.45 \%$ and supplemented with $10 \%$ heat inactivated FBS (Fetal bovine serum), 100 units $/ \mathrm{mL}$ of penicillin and $100 \mathrm{mg} / \mathrm{mL}$ of streptomycin and maintained at $37^{\circ}$ in a humidified atmosphere containing $5 \% \mathrm{CO}_{2}$. The cells were maintained as "monolayer culture" by serial sub-culturing.

\section{Sulforhodamine-B cytotoxicity assay (SRB)}

Cytotoxicity was determined using SRB method as described in literatures [11-12]. Exponentially growing cells were collected using $0.25 \%$ Trypsin-EDTA and seeded in 96-well plates at 1000-2000 cells/well in RPMI1640supplemented medium. After $24 \mathrm{~h}$, cells were incubated for $72 \mathrm{~h}$ in presence of various concentrations of the different metal complexes. After $72 \mathrm{~h}$ treatment, the cells were fixed with $10 \%$ trichloroacetic acid for $1 \mathrm{~h}$ at $4{ }^{\circ} \mathrm{C}$. Wells were stained for $10 \mathrm{~min}$ at room temperature with $0.4 \% \mathrm{SRB}$ dissolved in $1 \%$ acetic acid. The plates were air dried for $24 \mathrm{~h}$ and the dye was solubilized with Tris- $\mathrm{HCl}$ for $5 \mathrm{~min}$ on a shaker at $1600 \mathrm{rpm}$. The optical density (OD) of each well was measured spectrophotometrically at $564 \mathrm{~nm}$ with an ELISA microplate reader (ChroMate-4300, FL, USA).

\section{Data analysis}

The dose response curve of compounds was analyzed using $\mathrm{E}_{\max }$ model, and the cell validity was calculated using equation 1.

$$
\% \text { Cell viability }=(100-\mathrm{R}) \times\left(1-\frac{[\mathrm{D}]^{\mathrm{m}}}{\mathrm{K}_{\mathrm{d}}{ }^{\mathrm{m}}+[\mathrm{D}]^{\mathrm{m}}}\right)+\mathrm{R}
$$

where $\mathrm{R}$ is the residual unaffected fraction (the resistance fraction), [D] is the metal complex concentration used, $\mathrm{K}_{\mathrm{d}}$ is the concentration of the different metal complexes that produces a $50 \%$ reduction of the maximum inhibition rate and $\mathrm{m}$ is a Hill-type coefficient. $\mathrm{IC}_{50}$ was defined as the concentration required to reduce fluorescence to $50 \%$ of that of the control (i.e., $\mathrm{K}_{\mathrm{d}}=\mathrm{IC}_{50}$ when $\mathrm{R}=0$ and $\mathrm{E}_{\max }=100-\mathrm{R}$ ) [13].

\section{Surface activity calculations \\ Critical micelle concentration $(C M C)$}

The critical micelle concentration $(C M C)$ is defined as the concentration of surfactant in the solution at which the micelles are started to form. It can be determined from the extrapolation of the pre- and post micellar regions of the surface tension versus $-\log C$ profile [10].

\section{Effectiveness $\left(\pi_{\mathrm{cmc}}\right)$}

The effectiveness $\left(\pi_{\mathrm{cmc}}\right)$ is the difference between the surface tension of the bidistilled water and the surfactant solution at $C M C$ according to equation (2):

$$
\pi_{\mathrm{cmc}}=\gamma_{\mathrm{o}}-\gamma_{\mathrm{cmc}}
$$


where $\gamma_{\mathrm{o}}$ is the surface tension of the bidistilled water $(71.8 \mathrm{mN} / \mathrm{m})$ and $\gamma_{\mathrm{cmc}}$ is the surface tension of the surfactant solution at $C M C$ [14].

Maximum surface excess $\left(\Gamma_{\max }\right)$

The maximum surface excess $\left(\Gamma_{\max }\right)$ is defined as the maximum concentration of surfactant molecules which can be attained at the air - solution interface and can be calculated according equation (3) [15]:

$$
\Gamma_{\max }=(\partial \gamma / \partial \ln C) / R T
$$

where $R$ is the gas constant (8.314) and $T$ is the absolute temperature $\left({ }^{\circ} \mathrm{K}\right)$.

\section{Minimum surface area $\left(A_{\text {min }}\right)$}

Minimum surface area $\left(A_{\min }\right)$ is the area occupied by each surfactant molecule at the air/solution interface at the maximum saturation condition and can be calculated using equation (4) [15]:

$$
A_{\min }=10^{16} /\left(N_{\mathrm{av}} \Gamma_{\max }\right)
$$

where $\Gamma_{\max }$ is the maximum surface excess, $N_{\text {av }}$ is the Avogadro's number $\left(6.023 \times 10^{23}\right.$ molecule $\left.^{-1}{ }^{-1}\right)$ and $A_{\min }$ is given in $\mathrm{nm}^{2}$ molecule ${ }^{-1}$.

\section{Structure}

\section{Results and Discussion}

The chemical structures of the parent cationic surfactants (VSBO VSBD VSBH) were described in details in our previous work [9].The chemical structures of the synthesized metal complexes were confirmed using FTIR spectra: $1639 \mathrm{~cm}^{-1}(\mathrm{C}=\mathrm{N}), 880 \mathrm{~cm}^{-1}$ (aromatic protons), $2927 \mathrm{~cm}^{-1}\left(\mathrm{CH}_{2}\right), 2853 \mathrm{~cm}^{-1}\left(\mathrm{CH}_{3}\right), 3034$, $1497 \mathrm{~cm}^{-1}\left(\mathrm{~N}^{+}\right), 1050 \mathrm{~cm}^{-1}\left(\mathrm{O}-\mathrm{CH}_{3}\right)$, Figure 1.

${ }^{1} \mathrm{H}$-NMR spectra of the cobalt complex of dodecyl derivative (Co-VSBD) in $\mathrm{CDCl}_{3}$ as a solvent showed the following: $0.96 \mathrm{ppm}\left(\mathrm{t}, 6 \mathrm{H}, \mathrm{CH}_{3}\right), 1.3 \mathrm{ppm}\left(\mathrm{m}, 40 \mathrm{H}, \mathrm{CH}_{2}\left[\mathrm{CH}_{2}\right]_{10} \mathrm{CH}_{3}\right), 3.73 \mathrm{ppm}\left(\mathrm{s}, 6 \mathrm{H}, \mathrm{OCH}_{3}\right), 4.19 \mathrm{ppm}(\mathrm{t}$, $\left.4 \mathrm{H}, \mathrm{COOCH}_{2}\right), 7.26 \mathrm{ppm}$ (t, $4 \mathrm{H}$, benzylidenimine), $7.33 \mathrm{ppm}, 8.1 \mathrm{ppm}\left(\mathrm{s}, 2 \mathrm{H}, \mathrm{N}=\mathrm{CH}\right.$ azomethine). ${ }^{13} \mathrm{C}-\mathrm{NMR}$ $\left(\mathrm{CDCl}_{3}\right)$ : $14.1 \mathrm{ppm}\left(\mathrm{CH}_{3}\right), 22.8 \mathrm{ppm}\left(\mathrm{CH}_{2} \mathrm{CH}_{3}\right), 29.7 \mathrm{ppm}\left(\left[\mathrm{CH}_{2}\right]_{9}\right), 55.9 \mathrm{ppm}\left(\mathrm{OCH}_{3}\right), 63.2 \mathrm{ppm}\left(\mathrm{OCH}_{2}\right), 118.3$ ppm $(\mathrm{CH}=\mathrm{CH}$ benzylidenimine $), 161 \mathrm{ppm}\left(\mathrm{COOCH}_{2}\right), 174 \mathrm{ppm}(\mathrm{N}=\mathrm{CH}$ azomethine).The analytical data confirmed the chemical structures of the synthesized metal complexes as represented in Scheme 1.

\section{UV-Vis spectroscopy}

UV-visible absorption spectra are very sensitive to formation of metal complexes, due to metal complexes exhibit intense absorption peaks correspond to the bond formation between the metal ions and the ligands. The UV spectra of the cationic Schiff bases represent two absorption bands: the first located at $208 \mathrm{~nm}$ corresponds to $\pi-\pi^{*}$ electronic transition; while the second located at $250 \mathrm{~nm}$ corresponds to $\mathrm{n}-\pi^{*}$ electronic transition of the benzene and pyridine rings, respectively [16]. Figure 2a-d represents the UV-spectra of the synthesized $\mathrm{Cu}(\mathrm{II}), \mathrm{Co}(\mathrm{II}), \mathrm{Ni}(\mathrm{II})$, and $\mathrm{Y}$ (III) metal complexes (representatively for VSBH). Figure 2a-drecords appearance of new absorption band in the range of 336-344 $\mathrm{nm}$ corresponds to the metal complex formation. The new absorption band is due to the electronic transition of $d$-orbitals of the different transition metal ions incorporated in the metal complexes. Further analysis of UV spectra revealed that the new absorption bands appeared at higher wavelengths for larger diameter ions (e.g., Ni, ca. $344 \mathrm{~nm}, \mathrm{Y}$, ca. $342 \mathrm{~nm}$ ), while for the smaller ion, $\mathrm{Cu}(\mathrm{II})$, the absorption band appeared at lower wavelength $(336 \mathrm{~nm})$. That indicates a higher energy is required for $d$-electrons transition in case of $\mathrm{Cu}$ (II) ions, due to its small ionic radius. In case of Y(III) and $\mathrm{Ni}(\mathrm{II})$, the ionic radii are larger and the energies required for $d$-electrons transition are less than that of $\mathrm{Cu}(\mathrm{II})$. Additionally, UV absorption spectra confirmed the formation of the metal complexes of the cationic Schiff base surfactants.

\section{Particle size and zeta potential}

The metal complexes were characterized using dynamic light scattering (DLS). In general, the DLS analyses of the different metal complexes presented bimodal distributions, (Figure $3 \boldsymbol{a}$-d $\boldsymbol{d}$ ). The distribution had a major peak at certain particle size diameter with area intensity $\%$ for each metal complex. $\mathrm{Cu}(\mathrm{II})=58 \mathrm{~nm}$ (98.1\%area intensity), Co(II) $=90 \mathrm{~nm}(100 \%$ area intensity), Ni(II) $=95 \mathrm{~nm}(98.5 \%$ area intensity), and Y(III) $=$ $159 \mathrm{~nm}$ (93.6\% area intensity), Table 1. Size (including size distribution) and zeta potential are essential characteristic parameters for complexes formation [17]. Figure 3a-d showed size distribution profiles of the metal complexes of $\mathrm{Cu}(\mathrm{II}), \mathrm{Co}(\mathrm{II}), \mathrm{Ni}(\mathrm{II})$, and $\mathrm{Y}(\mathrm{III})$ with the cationic Schiff bases (representatively for VSBH). According to particle size distribution measurements (by number) (Figure 4a-d), the particle size were in the range of:43-58 nm for $\mathrm{Cu}(\mathrm{II}), 86-91 \mathrm{~nm}$ for $\mathrm{Co}(\mathrm{II}), 78-105 \mathrm{~nm}$ for $\mathrm{Ni}(\mathrm{II})$, and 122-164 nm for $\mathrm{Y}$ (III) metal complexes. It is clear that the particle size range of the different metal complexes is mainly depends on the ionic radius of the metal ions [17]. While, the chain length of the hydrophobic chains (alkyl chains: octyl, dodecyl, and hexadecyl) plays a minor effect on the particle size of the complexes. The maximum particle size of the metal complexes can be arranged in the following order: $\mathrm{Y}(\mathrm{III})>\mathrm{Ni}(\mathrm{II})>\mathrm{Co}(\mathrm{II})>\mathrm{Cu}(\mathrm{II})$. 
The polydispersity index (PDI) describes the particle sizes distribution of the formed metal complexes. PDI more than unity indicates the scattering of metal complex diameter range with low intensity, while smaller PDI than unity indicates narrow range of complex molecules diameter formed. It is clear that PDI of the synthesized metal complexes is always lower than 1, indicating the narrow size and low scattering of the formed metal complex molecules. PDI increased by increasing the ionic radius of the metal ions in the following order: $\mathrm{Y}(\mathrm{III})>\mathrm{Ni}(\mathrm{II})>\mathrm{Co}(\mathrm{II})>\mathrm{Cu}(\mathrm{II})$, with values of $0.89,0.82,0.39$, and 0.35 , respectively (Table 1). Increasing PDI by increasing the metal ion diameter may be due to large size of the metal complexes. $\mathrm{Cu}$-complex has the smallest ionic radius $(\mathrm{PDI}=0.35)$ which is completely covered by the ligands molecules. On contrarily, Y-complex has the largest ionic radius, hence the covering of metal ion surface by the ligands is incompletely, hence PDI increased to 0.89 .

The surface conductivity of the different metal complex molecules showed the degree of charge accumulations on these molecules. Increasing the metal ion radius and the number of $d$-or $f$-electrons increases the conductivity of these molecules. It is clear from conductivity values of the metal complexes (Table 1) that the increase of ionic radius increases the conductivity of the metal complex molecules. The highest molecular conductivity obtained in case of $\mathrm{Y}(\mathrm{III})$ complex $(0.407 \mathrm{mS} / \mathrm{cm})$; while the lowest obtained for $\mathrm{Cu}(\mathrm{II})$ complex at $0.221 \mathrm{mS} / \mathrm{cm}$.

Stability of the metal complexes is crucially important for many applications and can be determined using zeta potential measurements [18]. Zeta potential is the net surface charge of the nanoparticles when they are inside a solution. The fact that complex particles push each other and their agglomeration behavior depends on large negative or positive zeta potential. The zeta potential playing an important role limits in the stability of solutions is $+30 \mathrm{mV}$ or $-30 \mathrm{mV}$ [19]. The zeta potential of the synthesized metal complexes (representatively for VSBO complexes of $\mathrm{Y}(\mathrm{III}), \mathrm{Ni}(\mathrm{II}), \mathrm{Co}(\mathrm{II})$, and $\mathrm{Cu}(\mathrm{II})$ are always in positive values and higher than $50 \mathrm{mV}$. That showed the stability of the metal complexes in their solutions and the coagulation of the molecules is occurred rarely. That was in a good agreement with the polydispersity index values and the particle size distribution measurements (by number). The positive values of zeta potentials of the metal complexes are in good agreement with published data and findings. The positively charged metal ions surrounded by cationic surfactants are characterized by positive zeta potential values. Positive zeta potential values in presence of cationic surfactants indicate the formation of some kind of bilayer of surfactants on the complex particles [20].

\section{Surface activity}

Figures 5-6 represent the surface tension versus - $\log$ concentration of the synthesized cationic surfactants and their metal complexes (representatively for VSBO metal complexes) at $25{ }^{\circ} \mathrm{C}$. At the start, the surface tension of the solutions sharply decreased upon increasing the surfactant concentration, but its variation became less pronounced when the concentration reached certain value. The profile represents typical relation between the surface tension-concentration profiles of the parent surfactants [21] with the two characteristic regions. The critical micelle concentration (CMC) was one of the major performance parameters of surfactant, which could be directly interpreted from the transition point indicated in Figure 6.The critical micelle concentration values of the different metal complexes and their parent cationic surfactants were listed in Table 2. CMC values of the metal complexes are gradually decreased by changing the metal in the following sequence: $\mathrm{Y}, \mathrm{Ni}, \mathrm{Cu}$ and $\mathrm{Cu}$. That can be attributed to the ionic radius of the transition metal participate in the metal complex molecule formation. Yttrium ion has the largest radius which accompanied by the largest CMC value. The order of CMC variation of the different metal complexes which contain similar transition metal and different cationic surfactant as a ligand is similar to the sequence in their parent cationic surfactants. That indicates the effective role of the parent cationic surfactants on the surface activity of the different metal complexes. Increasing the alkyl chain length of the cationic surfactants participated in the complexes decreases their CMC values considerably. Comparing the values of CMC of the metal complexes and their parent cationic surfactants revealed that the complexation enhanced the micellization process at lower concentrations.

The enhancement of the micellization at lower concentrations can be described in term of surface pressure. The complex molecules have larger size at the interface and in the bulk of the solution, as well as the complex molecules are more hydrophobic that the individual cationic surfactants. That increases the repulsion between the complex molecules and the aqueous phase. As a result, the surface pressure increases which leads to increase the surface concentration to the maximum. The high surface concentration forced the adsorbed molecules to undergo to the bulk of their solution in the form of micelles. Consequently, micelles are formed at relatively lower concentrations, as listed in Table 2. The high surface pressure of the molecules indicates their high concentration at the interface, Yttrium metal complexes has the highest surface concentration at the interface, while cobalt complexes own the lowest values.

Higher surface concentration indicates the compactness of the molecules at the interface, which indicates that the molecules are well organized at that interface. The compactness at the interface decreases the area occupied by each molecules at that interface. The VSBH metal complex derivatives have the lowest $\mathrm{A}_{\min }$ 
ranged between $80.3 \ddot{\mathrm{A}}$ and $105.5 \ddot{\mathrm{A}}$ at the interface. The most extended molecules at the interface were the VSBO metal complexes which have average surface area ranged between $109.2 \ddot{A}$ and $125.5 \ddot{A}$.

According to Table 2, another important parameter of surfactants, $P c_{20}$, could also be interpreted. $P c_{20}$ represented the concentration required to reduce the surface tension of water by $20 \mathrm{mN} / \mathrm{m}$, and reflected the capability of surfactants adsorbing on the air/solution interface [22], and the less the $P c_{20}$ value was, the greater the adsorbing efficiency was. It is clear that the metal complexes of VSBO cationic surfactants have higher $P c_{20}$ than their parent cationic. Furthermore, the efficiency values of VSBD and VSBH metal complexes were lower than the parent cationic surfactants. That indicates that the complexation improved the surface activity of the cationic surfactants. The phenomenon indicated that the molecules of the metal complexes of VSBD and VSBH cationic surfactants can cover the water surface much effective than the VSBO metal complexes do. It is clear that the effectiveness values of the metal complexes are always higher that their parent cationic surfactants. That indicates the high surface activity of these metal complexes and their tendency to reduce the surface tension of their solutions at the interface [23].

\section{Thermodynamic functions of the cationic surfactants metal complexes}

The thermodynamic parameters of adsorption and micellization are determined the tendency of the surfactant molecules towards adsorption at the interface or micellization in the bulk of their solutions.

The standard free energy of micellization $\left(\Delta G_{\text {mic }}\right)$ is the energy loss in the system due to the transfer of one mole of surfactant molecule from the adsorbed monolayer at the air/solution interface to the bulk of the solution to from the micelles, and is calculated in $\mathrm{kJ} \mathrm{mol}^{-1}$ using Gibb's equation as represented in equation (4):

$$
\Delta G_{\text {mic }}=-2.303 R T(1-n) \log C M C
$$

where $R$ is the gas constant $(8.314), T$ is the absolute temperature $\left({ }^{\circ} \mathrm{K}\right), n$ is the number of counter ions in case of ionic surfactants and equal to zero in case of nonionic surfactants.

The adsorption free energy of $\left(\Delta G_{\text {ads }}\right)$ is the energy loss of the system due to the ordered adsorption of one mole of surfactants at the air/solution interface and given in $\mathrm{kJ} \mathrm{mol}^{-1}$ by:

$$
\Delta G_{\text {ads }}=\Delta G_{\text {mic }}-\left(0.6023 \times \pi_{\mathrm{cmc}} \times A_{\min } / 1000\right)
$$

where $\Delta G_{\text {mic }}$ is the standard free energy of micellization in $\mathrm{kJ} \mathrm{mol}^{-1}, \pi_{\mathrm{cmc}}$ is the effectiveness in $(\mathrm{mN} / \mathrm{m})$ and $A_{\min }$ is the minimum surface area at the interface by each molecule in $\mathrm{nm}^{2}$.

The free energies of micellization and adsorption of the prepared metal complex surfactants are always in negative values indicating that the two processes are occurred spontaneously, Table 2 . The negative sign of both micellization and adsorption processes indicates the presence of equilibrium between the adsorbed molecules at the interface and the micellized molecules in the bulk. It is also obvious from data in Table $\mathbf{2}$ that the adsorption free energies are more negative than the micellization free energies. That is an evidence for the preferential tendency of the prepared metal complexes towards adsorption at the air/water interface than the formation of micelles in the bulk of their solutions (i.e., micellization). The adsorption tendency of the different mental complexes expressed in term of $\Delta \mathrm{G}_{\text {ads }}$ is greater than the micellization tendency, which indicates that these complexes have high potential in the medicinal applications. These applications include adsorption of the molecules at the cellular membrane of the different cells, tissue cells, bacterial and organism's cells to act well.

\section{Antitumor activity}

The synthesized metal complexes were applied in the medicinal field as anticancer agent. Their action mode is complicated, but simply it required these molecules to be adsorbed at the cellular membranes of the tissues [24]. In order to determine the possible anticancer activity of our compounds, huh-7 human hepatocellular carcinoma cell line, was cultured in a monolayer and treated with each of our compounds for 48 $h$. The SRB assay was then performed to assess the rate of cellular proliferation, and the resulting growth curves showed that our molecules exhibited cytotoxicity against the above mentioned cell line with very low $\mathrm{IC}_{50}$ values.

It is clear from data listed in Table 3 which were extracted from the validity figures (Figure $7 \boldsymbol{a}, \boldsymbol{b})$ of the different metal complexes that the nickel complexes exerted the most powerful cytotoxic effect against huh-7 cells with very low $\mathrm{IC}_{50}$ value $\left(\mathrm{IC}_{50}\right.$ values were 43,21 and $8 \mu \mathrm{g} / \mathrm{ml}$ for Ni-VSBO, Ni-VSBD and Ni-VSBH, respectively). On the other hand, $\mathrm{Cu}$ and $\mathrm{Co}$ metal complexes showed moderate efficiency against huh-7 cells. While, yttrium metal complexes had the lowest activity against the growth of huh-7 cells.

Inspection of Table 3 revealed that, the metal complexes of the VSBH showed the highest activity against the growth of huh-7 cells. The obtained toxicities ( $\mathrm{IC}_{50}$ ) were: $59,27,24$ and $8 \mu \mathrm{g} / \mathrm{ml}$ for $\mathrm{VSBH}-\mathrm{Y}$, VSBH-Cu, VSBH-Co and VSBH-Ni, respectively.

The obtained toxicity values $\left(\mathrm{IC}_{50}\right)$ showed two characteristics of the tested compounds:

1. The efficiency of the metal complexes depends on the type of the transition metal within the same series [25], i.e., when the cationic surfactant (ligand) is fixed. More the electronegative transition metal is more the anticancer agent effective for growth of huh-7 cells. 
2. At the different cationic surfactants (different ligand), the alkyl chain length plays an important role in the efficiency of the metal complexes [25-26]. Increasing the alkyl chain length increases the efficiency of the metal complexes as anticancer agents.

[1] T.W. Hambley, Dalton Trans 7 (2007) 4929.

\section{References}

[2] C. Orvig and M.J. Abrams, Chem Rev 99 (1999) 2201

[3] Z.Guo andP.J.Sadler, Angew Chem Int Ed 38 (1999) 1512

[4] K.H. Thompson and C. Orvig, Dalton Trans 6 (2006) 761.

[5] Y. Jung and S.J. Lippard, Chem Rev107 (2007) 1387.

[6] S. Van Zutphen and J. Reedijk, Coord Chem Rev 249 (2005) 2845.

[7] A.M. Badawi, N. Zachary, S.M. Morsy, G. Sabry, M. Foad and A. Mousa, J American Sci 8 (2012) 763.

[8] A.M. Badawi, A.S. Mekawi, M.Z. Mohamed, M.M. Khowdairy, J Cancer Res Therap 3 (2009) 198.

[9] N.A. Negm, N.G. Kandile, I.A. Aiad and M.A. Mohammad Colloids and Surfaces A: Physicochem. Eng. Aspects 391 (2011) 224.

[10] N.A. Negm and A.S. Mohamed, J Surfact Deterg 7 (2004) 23.

[11] A.R. Pombinho, V. Laizé, D.M. Molha, S.M.P. Marques and M.L. Cancela, Cell and Tissue Res 315 (2004) 393.

[12] P. Skehan, R. Storeng, D. Scudiero, A. Monks, J. McMahon, D. Vistica, J.T. Warren, H. Bokesch, S. Kenney and M.R. Boyd, J Natl Cancer Inst 82 (1990) 1107

[13] A.M. Al-Abd, J.H. Lee, S.Y. Kim, N. Kun and H.J. Kuh, Cancer Sci 99 (2008) 423.

[14] N.A. Negm, I.A. Aiad, J Surf Deterg 10 (2007) 87.

[15] N.A. Negm, J. Surf. Deterg. 10 (2007) 71.

[16] A.S. El-Tabl, R.M. El-Bahnasawy, M.M.E. Shakdofa, A.E. Abdalah, J. Chem. Res. 88 (2010) 210.

[17] R. H. Müller, C. Jacobs, O. Kayser, Advanced Drug Delivery Reviews, 47(2001) 3-19.

[18] Y. Zhang, M. Yang, N.G. Portney, D. Cui, G. Budak, E. Ozbay, M. Ozkan, C.S. Ozkan, Biomed. Microdevices 10 (2008) 321.

[19] J. Ho, M.K. Danquah, H. Wang, G.M. Forde, J. Chem. Technol. Biotechnol. 83 (2008) 351.

[20] J. Hedberg, M. Lundin, T. Lowe, E. Blomberg, S. Woold, I.O. Wallinder, J. Colloid. Interface Sci. 269 (2012) 193.

[21] N.A. Negm, A.F. El Farargy, D.E. Mohamed and H.N. Mohamed, J Surfact Deterg 15 (2012) 433.

[22] S. Zhu, L. Liu, F. Cheng, J Surfact Deterg 14 (2010) 221

[23] M. Rosen and J. Geminis, Chem Technol 23 (1993) 30.

[24] J. Loa, P. Chow and K. Zhang, Cancer Chemother Pharmacol 63 (2009) 1007.

[25] S.Y. Lee, I. Peckermann, E. Abinet, J. Okuda, G. Henze and A. Prokop, Med Oncol 29 (2012) 235.

[26] M.C. Miller, A. Sood, B.F. Spievogel and I.H. Hall, Appl Organometal Chem 12 (1998) 87.

\section{Figures captions:}

Figure 1: IR spectra of cobalt complex of VSBD derivative.

Figure 2: UV-Vis spectra of cationic Schiff base complexes with: (a) Cu(II); (b) Co(II); (c) Ni(II); (d) Y(III).

Figure 3: Particle size distribution measurements (by area) of cationic Schiff base complexes with: (a) $\mathrm{Cu}$ (II); (b) $\mathrm{Co}(\mathrm{II})$; (c) Ni(II); (d) Y(III).

Figure 4: Particle size distribution measurements (by number) of cationic Schiff base complexes with: (a) $\mathrm{Cu}(\mathrm{II})$; (b) $\mathrm{Co}(\mathrm{II})$; (c) Ni(II); (d) Y(III).

Figure 5: Surface tension vs. $-\log$ concentration of the cationic surfactants VSBO $(\diamond)$, VSBD $(\square)$ and VSBH $(\Delta)$ at $25^{\circ} \mathrm{C}$.

Figure 6: Surface tension vs. $-\log$ concentration of VSBH metal complexes at $25{ }^{\circ} \mathrm{C}$; Co $(\square), \mathrm{Cu}(\Delta), \mathrm{Ni}(\times), \mathrm{Y}$ $(*)$.

Figure 7: Validity of cationic surfactants metal complexes against the growth of huh-7 cells in $\mu \mathrm{g} / \mathrm{ml}$, a.: $\mathrm{Y}$ VSBO, b.: Ni-VSBD.

Table 1: Particle size distribution, major peak intensity \%, polydispersity index (PDI), zeta potential, and conductivity of the different metal complexes

\begin{tabular}{|c|c|c|c|c|c|c|}
\hline \multicolumn{2}{|c|}{ Metal complex } & \multirow{2}{*}{$\begin{array}{c}\text { Major peak particle size, } \\
\text { nm }\end{array}$} & \multirow{2}{*}{$\begin{array}{c}\text { Size diameter range, } \\
\mathbf{n m}\end{array}$} & \multirow{2}{*}{$\begin{array}{l}\text { Polydispersity index } \\
\text { (PDI) }\end{array}$} & \multirow{2}{*}{$\begin{array}{l}\text { Conductivity, } \\
\text { mS.cm }\end{array}$} & \multirow{2}{*}{$\begin{array}{l}\text { Zeta potential, } \\
\mathrm{mV}\end{array}$} \\
\hline Ligand & Metal ion & & & & & \\
\hline \multirow{4}{*}{ VSBO } & $\mathrm{Cu}(\mathrm{II})$ & 51 & $40-53$ & 0.31 & 0.220 & +39.2 \\
\hline & Co(II) & 79 & $52-84$ & 0.40 & 0.273 & +45.6 \\
\hline & $\mathbf{N i ( I I )}$ & 88 & $67-89$ & 0.78 & 0.350 & +61.7 \\
\hline & $\mathbf{Y}(\mathrm{III})$ & 147 & $101-155$ & 0.86 & 0.402 & +77.3 \\
\hline \multirow{4}{*}{ VSBD } & $\mathrm{Cu}(\mathrm{II})$ & 54 & $40-56$ & 0.32 & 0.219 & +40.0 \\
\hline & Co(II) & 82 & $60-88$ & 0.41 & 0.271 & +49.6 \\
\hline & $\mathbf{N i}(\mathbf{I I})$ & 90 & $72-100$ & 0.80 & 0.348 & +63.4 \\
\hline & $\mathbf{Y ( I I I )}$ & 151 & 113-160 & 0.87 & 0.400 & +78.2 \\
\hline \multirow{4}{*}{ VSBH } & $\mathrm{Cu}(\mathrm{II})$ & 58 & $43-58$ & 0.35 & 0.221 & +46.6 \\
\hline & Co(II) & 90 & 68-91 & 0.39 & 0.286 & +50.3 \\
\hline & $\mathbf{N i}(\mathrm{II})$ & 95 & $78-105$ & 0.82 & 0.351 & +68.5 \\
\hline & $\mathbf{Y}($ III) $)$ & 159 & $122-164$ & 0.89 & 0.407 & +81.2 \\
\hline
\end{tabular}


Anticancer cytotoxicity assessment of cationic surfactants metal complexes

Table 2: Surface active parameters of the metal complexes and their parent cationic surfactants at $25^{\circ} \mathrm{C}$

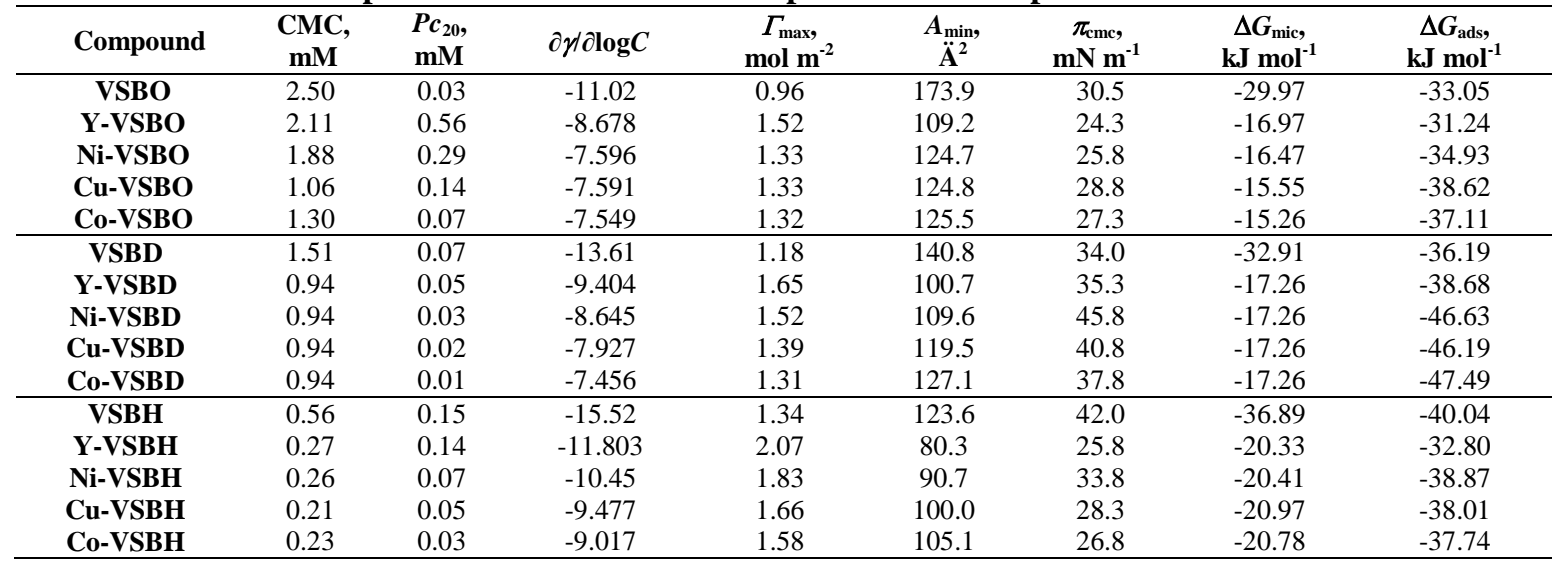

Table 3: $\mathrm{IC}_{50}$ of the tested compounds

\begin{tabular}{lr}
\hline Compound & IC $_{\mathbf{5 0}}$ \\
\hline Y-VSBO & 201 \\
Ni-VSBO & 43 \\
Cu-VSBO & 90 \\
Co-VSBO & 81 \\
\hline Y-VSBD & 160 \\
Ni-VSBD & 21 \\
Cu-VSBD & 56 \\
Co-VSBD & 30 \\
\hline Y-VSBH & 59 \\
Ni-VSBH & 8 \\
Cu-VSBH & 27 \\
Co-VSBH & 24 \\
\hline
\end{tabular}

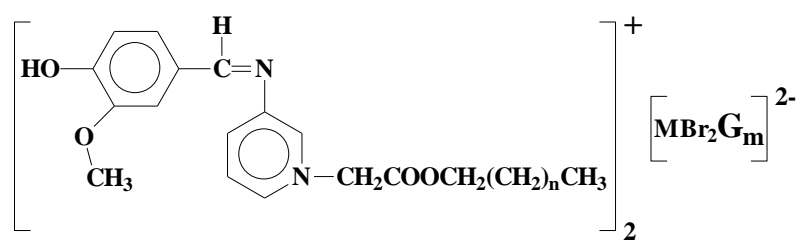

$\mathrm{n}=6$ (octyl derivative, VSBO), 10 (dodecyl derivative, VSBD), 14 (hexadecyl derivative, VSBH);

$\mathrm{G}=\mathrm{Cl}: \mathrm{M}=\mathrm{Cu}, \mathrm{Co}, \mathrm{Ni}, \mathrm{m}=\mathbf{2}$;

$\mathrm{G}=\mathrm{NO}_{3}: \mathrm{M}=\mathrm{Y}, \mathbf{m}=\mathbf{3}$

Scheme 1: Chemical structure of the synthesized metal complexes.

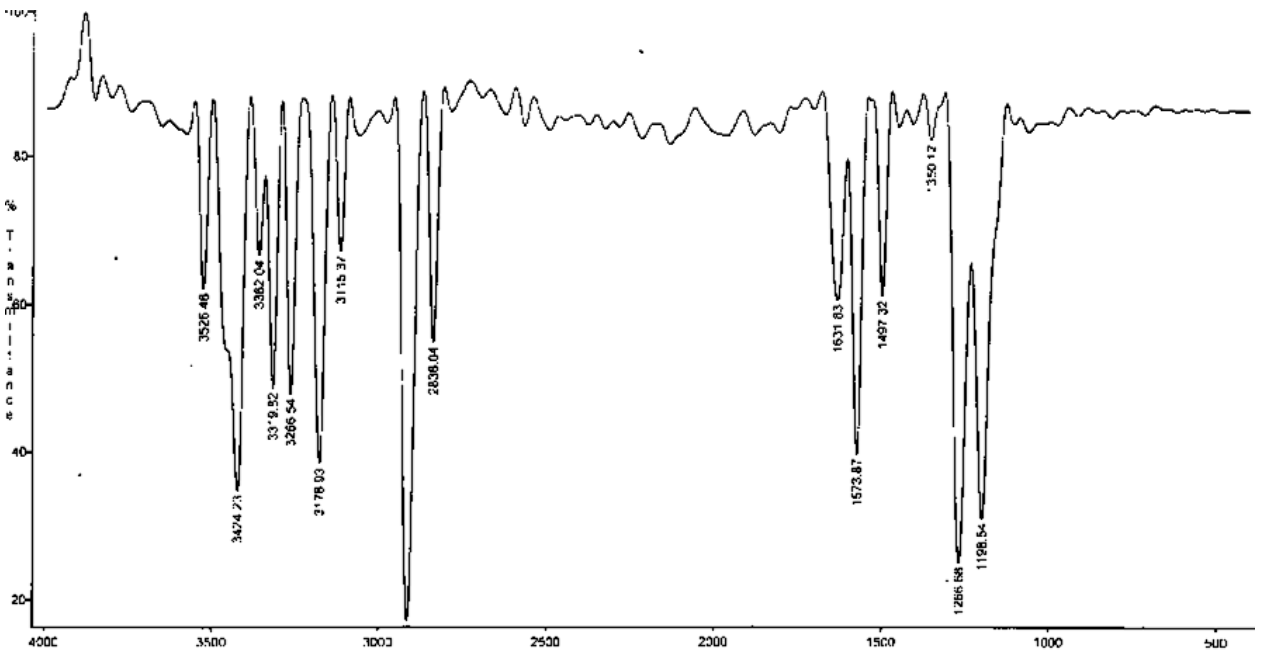

Figure 1: IR spectra of cobalt complex of VSBD derivative. 


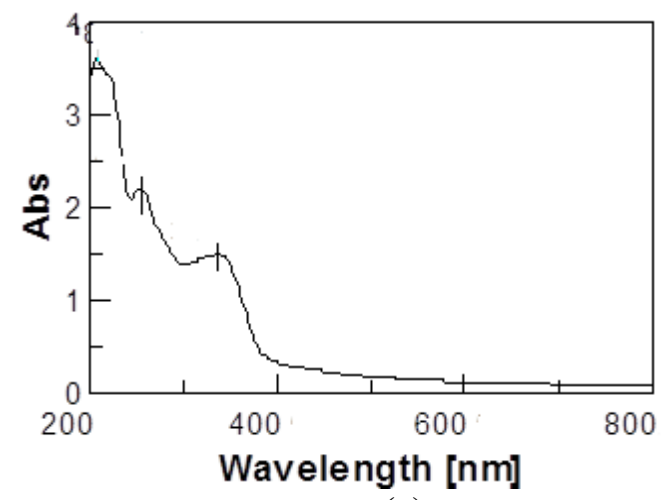

(a)

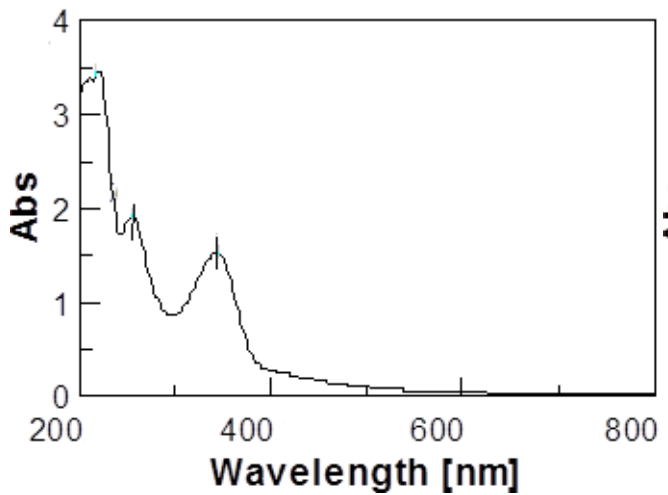

(b)

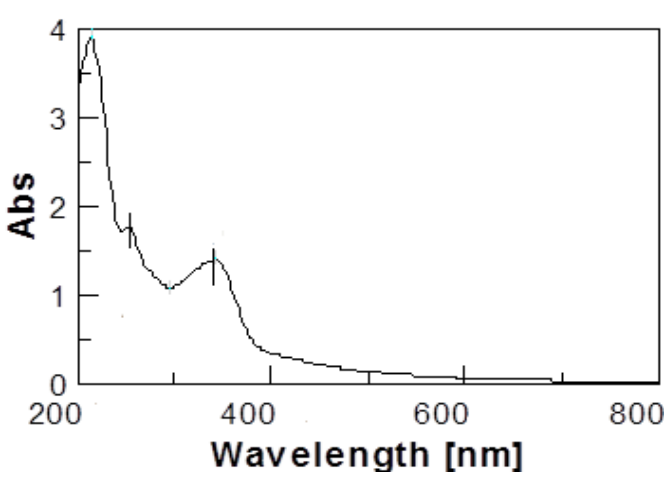

(b)

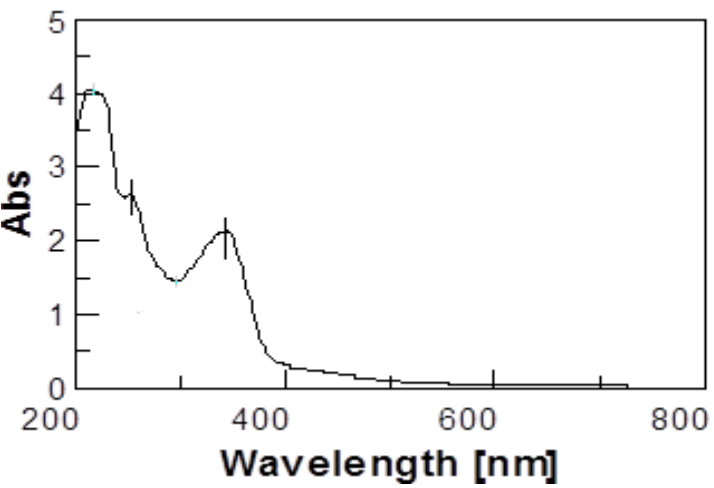

(d)

Figure 2: UV-Vis spectra of cationic Schiff base complexes with: (a) $\mathrm{Cu}(\mathrm{II})$; (b) $\mathrm{Co}$ (II); (c) Ni(II); (d) Y(III).

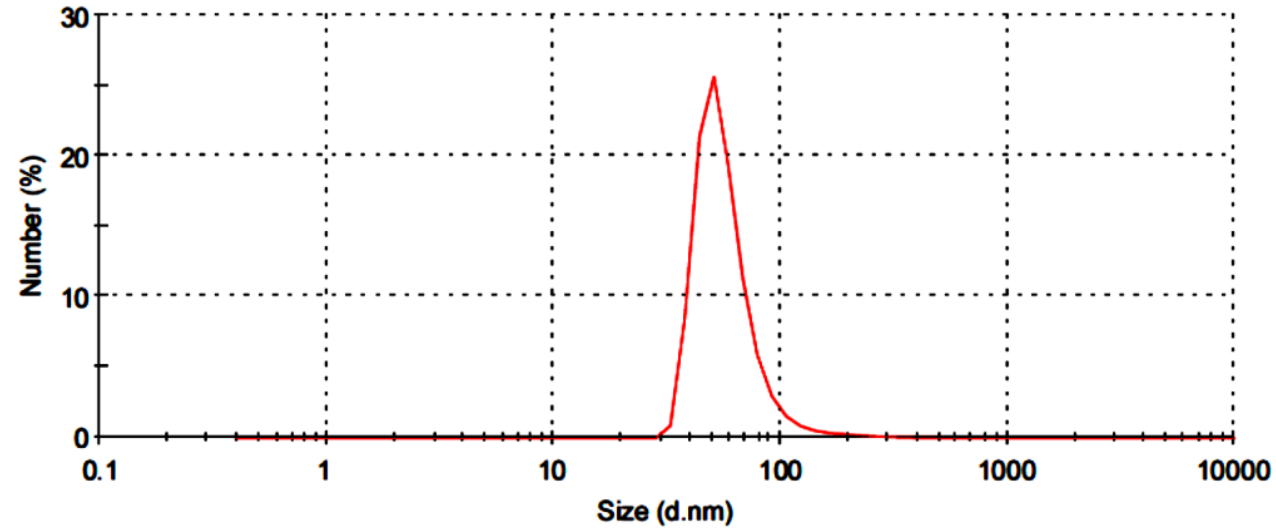

(a)

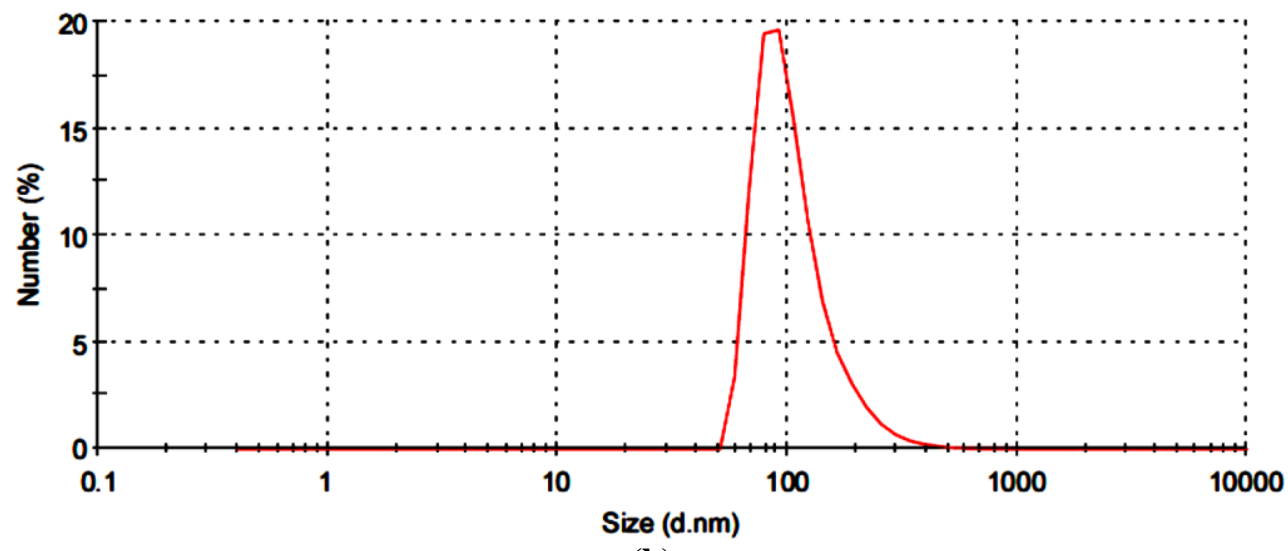

(b) 


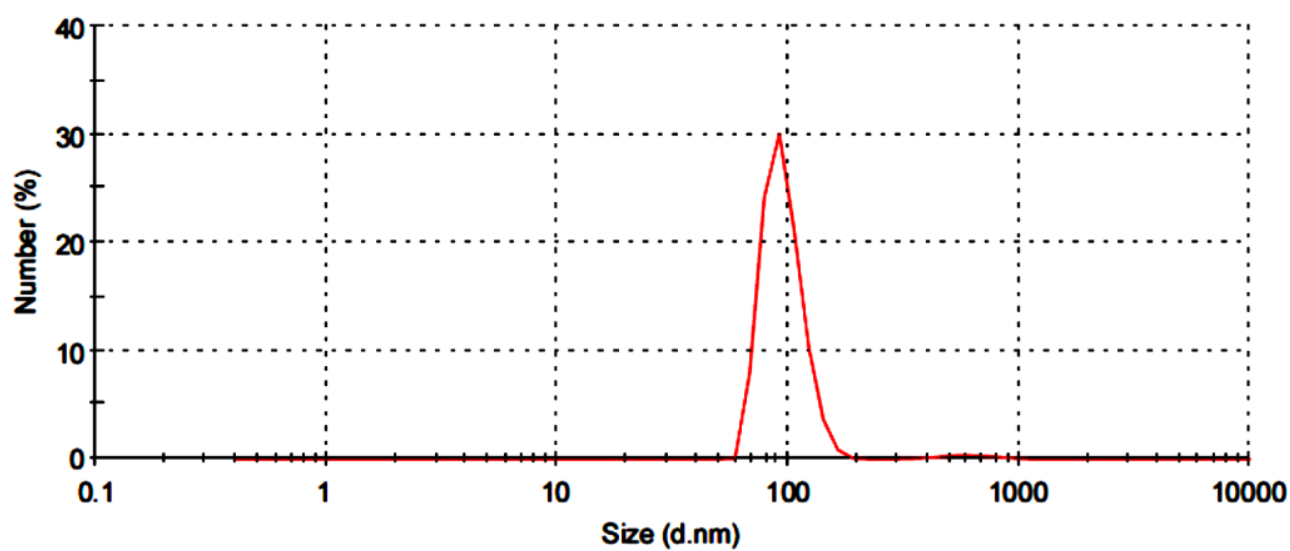

(c)

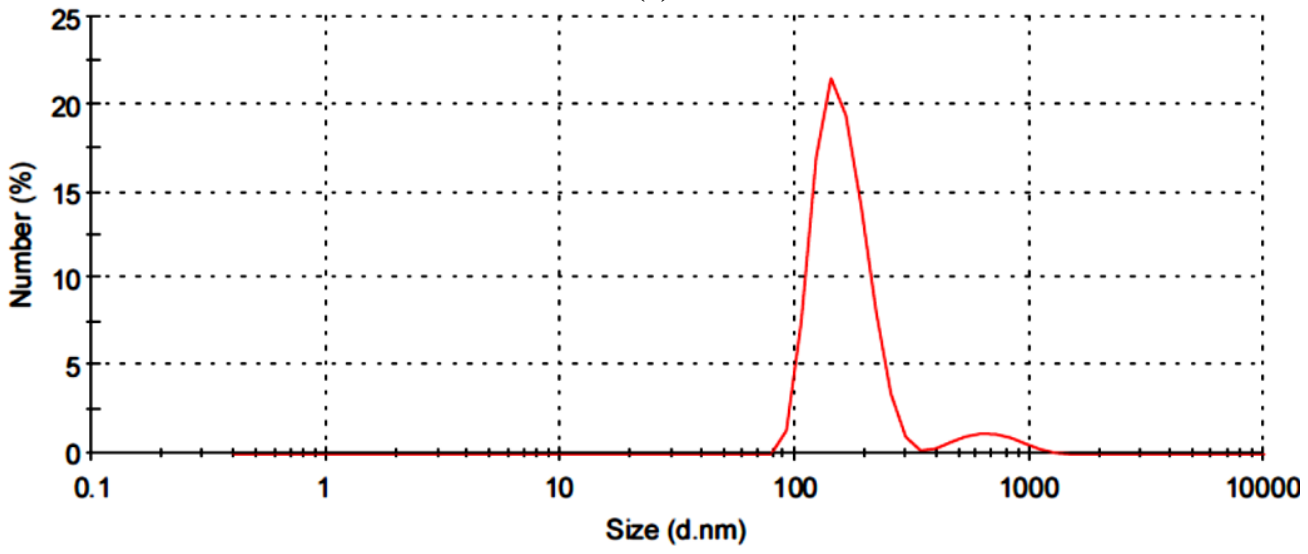

(d)

Figure 3: Particle size distribution measurements (by area) of cationic Schiff base complexes with: (a) $\mathrm{Cu}(\mathrm{II})$; (b) $\mathrm{Co}(\mathrm{II})$; (c) Ni(II); (d) Y(III).

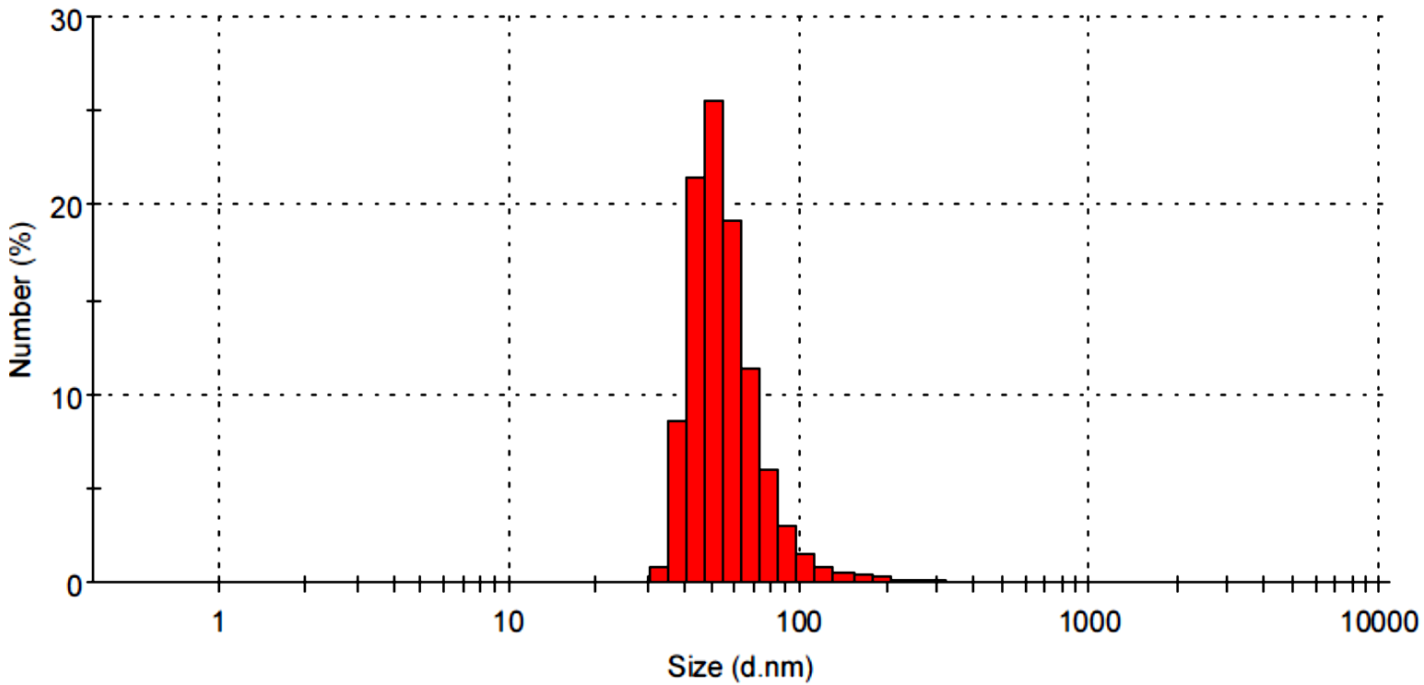

(a) 


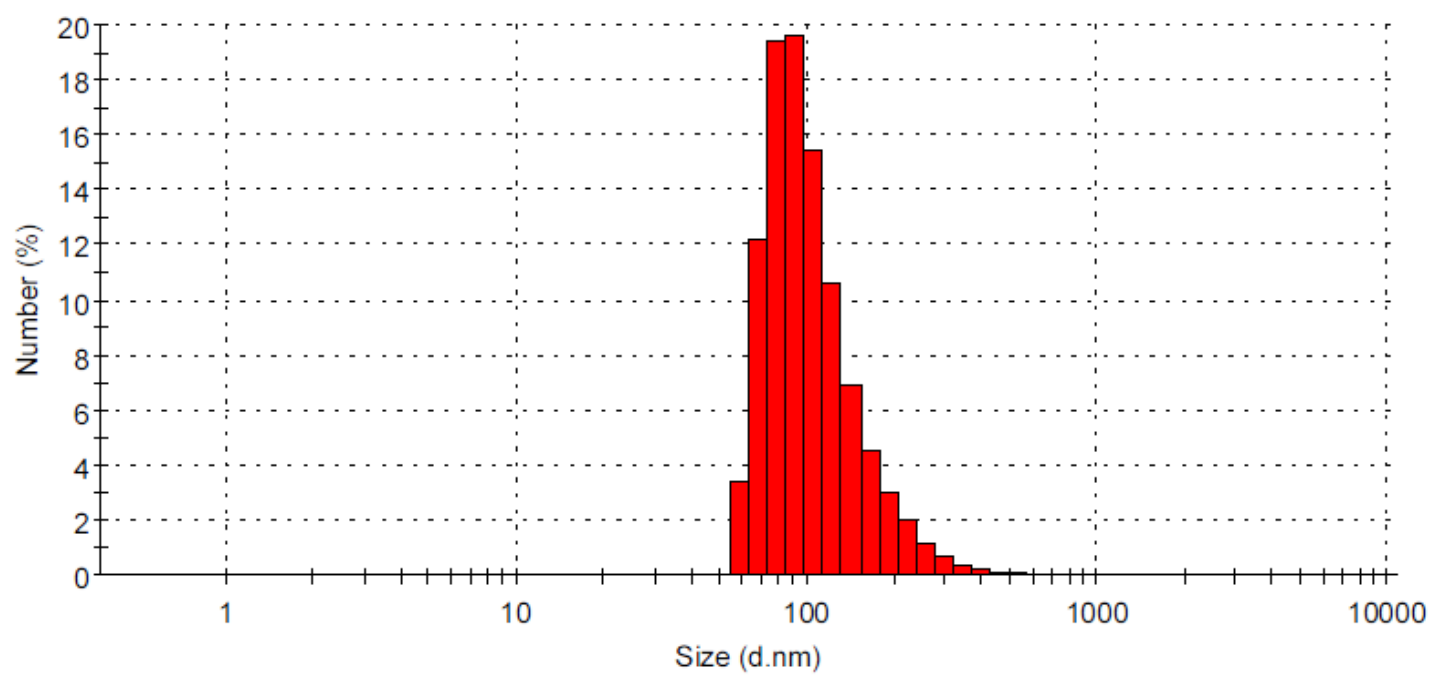

(b)

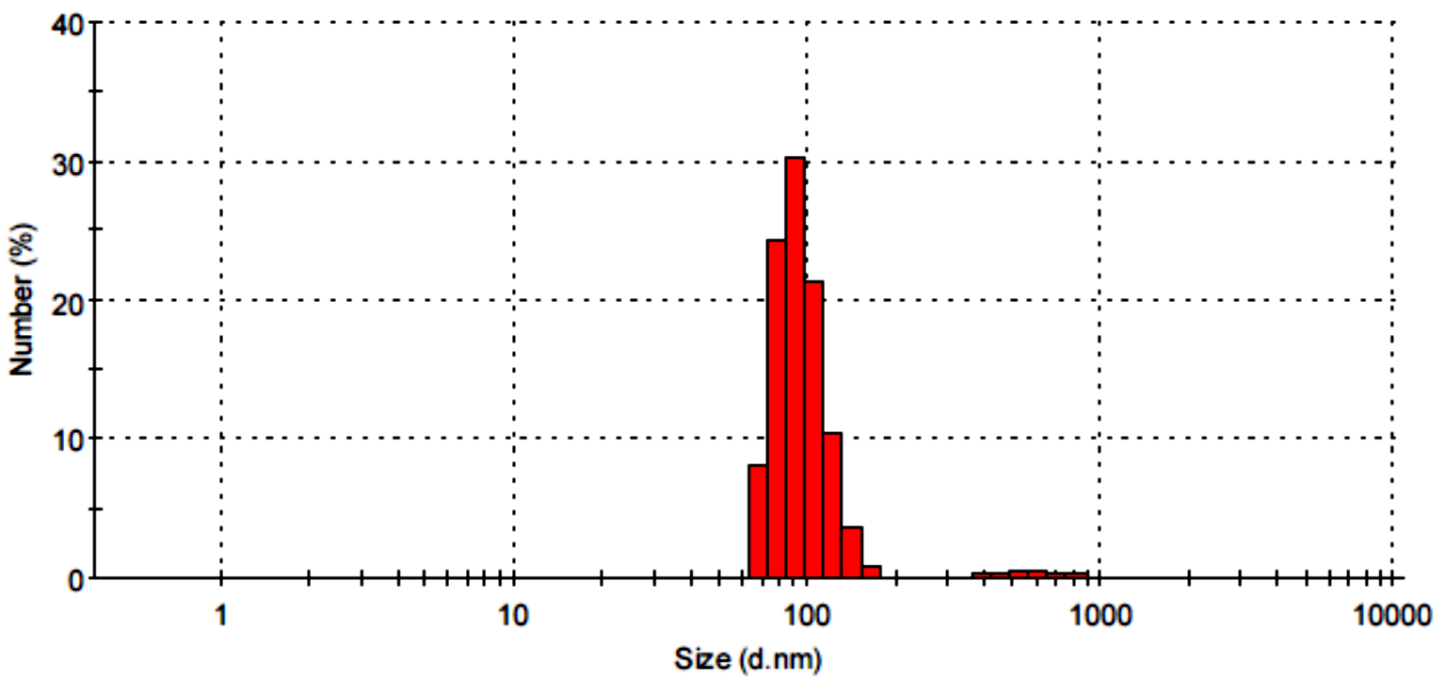

(c)

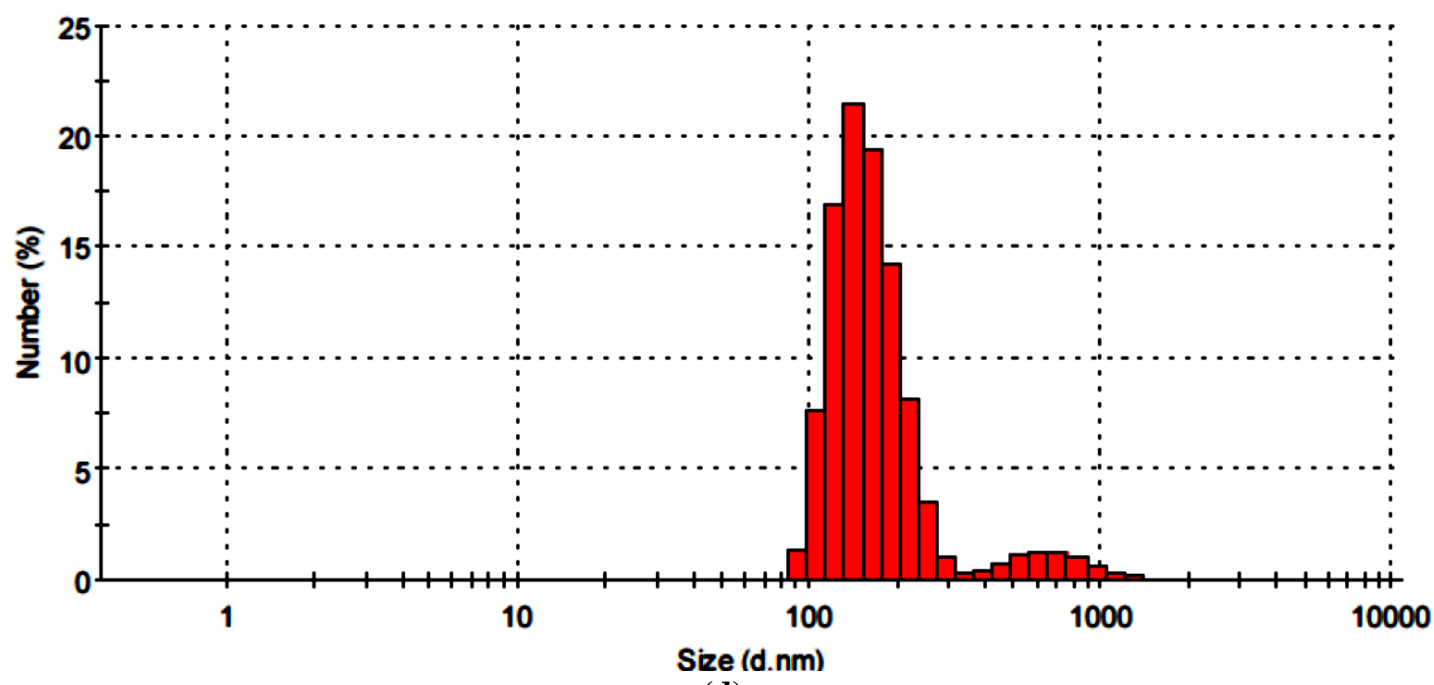

(d)

Figure 4: Particle size distribution measurements (by number) of cationic Schiff base complexes with: (a) $\mathrm{Cu}(\mathrm{II})$; (b) $\mathrm{Co}(\mathrm{II})$; (c) Ni(II); (d) Y(III). 


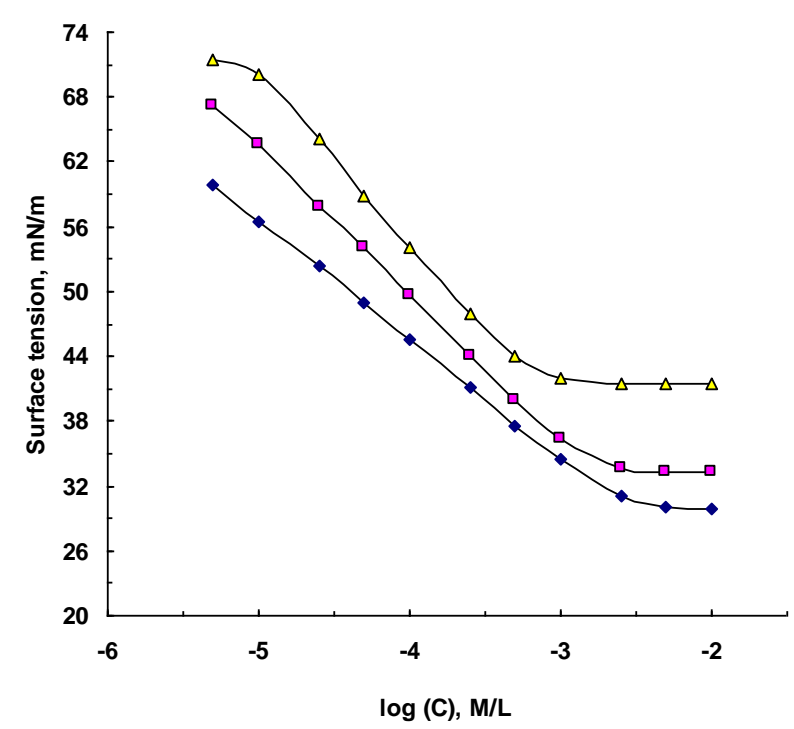

Figure 5: Surface tension vs. -log concentration of the cationic surfactants VSBO $(\diamond)$, VSBD ( $\square$ ) and $\operatorname{VSBH}(\Delta)$ at $25^{\circ} \mathrm{C}$.

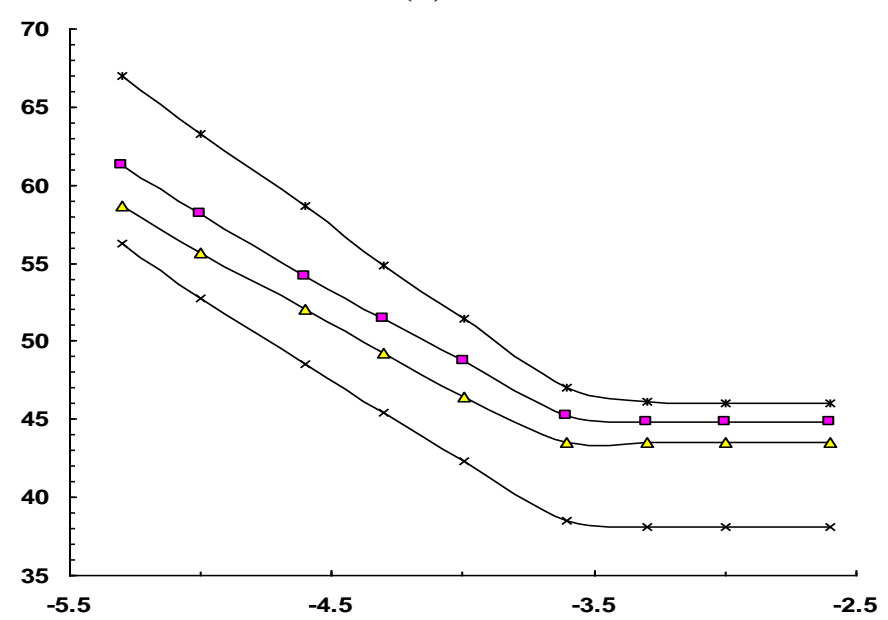

Figure 6: Surface tension vs. -log concentration of VSBH metal complexes at $25^{\circ} \mathrm{C}$; $\mathrm{Co}(\square), \mathrm{Cu}(\Delta), \mathrm{Ni}(\mathrm{x})$, $\mathbf{Y}(*)$.
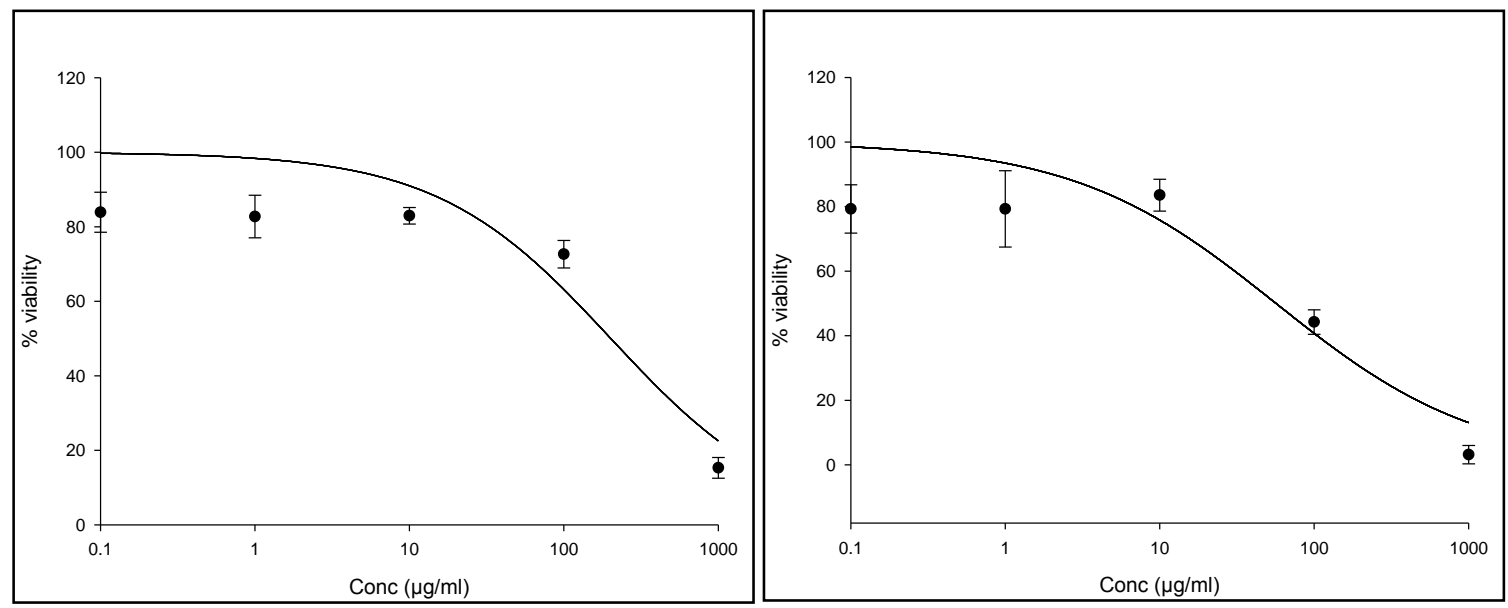

a.

b.

Figure 7: Validity of cationic surfactants metal complexes against the growth of huh-7 cells in $\mu \mathrm{g} / \mathrm{ml}$, a.: Y-VSBO, b.: Ni-VSBD. 